\title{
Note
}

\section{Dissolved air effects on lactose isomerisation and furosine formation during heat treatment of milk}

\author{
Maite RAdA-MendozAa, Mar Villamiel ${ }^{\text {b* }}$, Agustín Olano ${ }^{b}$ \\ a AECI scholar on leave from University of Cauca, Popayán, Colombia \\ b Instituto de Fermentaciones Industriales (CSIC), Juan de la Cierva 3, 28006 Madrid, Spain
}

(Received 7 September 2001; accepted 3 December 2001)

\begin{abstract}
The influence of dissolved air on lactose isomerisation and the Maillard reaction during heat treatment of milk was investigated, lactulose and furosine being the chemical parameters studied, respectively. For all treatments, the lowest contents of lactulose were found in samples bubbled with air, probably due to oxidative degradations during the heating of the milk. A lower formation of furosine was also detected in samples with air than in samples subjected to a previous de-aeration step. In the presence of oxygen, oxidative side reactions can take place leading to degradation of Amadori compounds. The results obtained in the present work point out the effect of dissolved air on lactose isomerisation and formation of Amadori compounds during the heat treatment of milk.
\end{abstract}

Air / lactulose / furosine / heating / milk

Résumé - Influence de l'air dissous sur l'isomérisation du lactose et la formation de furosine pendant le traitement thermique du lait. Nous avons étudié l'influence de l'air dissous sur l'isomérisation du lactose et la réaction de Maillard, pendant le traitement thermique du lait, par le dosage du lactulose et de la furosine, respectivement. Pour tous les traitements, les teneurs les plus basses en lactulose se trouvent dans les échantillons traités avec l'air, probablement en raison de la dégradation oxydative du lactulose lors du chauffage du lait. La concentration en furosine est plus faible dans les échantillons contenant de l'air que dans les échantillons soumis à une étape préalable de dé-aération. En présence d'oxygène, des réactions oxydatives secondaires peuvent avoir lieu, provoquant la dégradation du composé d'Amadori. Ces résultats montrent que la concentration d'oxygène du milieu influence notablement le taux d'isomérisation du lactose ainsi que la formation du composé d'Amadori, lors du traitement thermique du lait.

Air / lactulose / furosine / traitement thermique / lait

\footnotetext{
* Correspondence and reprints

Tel.: (34) 915622900 ext. 307; fax: (34) 9156448 53; e-mail: mvillamiel@ifi.csic.es
} 


\section{INTRODUCTION}

Milk contains dissolved air, whether it is obtained anaerobically or with access to air. Commercial raw milk contains about 15 and $6 \mathrm{mg} \cdot \mathrm{L}^{-1}$ of $\mathrm{N}_{2}$ and $\mathrm{O}_{2}$, respectively [7]. The presence of remaining oxygen may have a negative effect on the nutritional characteristics of the product; thus, several vitamins such as ascorbic acid, riboflavin, folic acid and vitamin A can be degraded under oxidative conditions [4, 19].

Another detrimental effect of the inclusion of air could be the separation of free fat from the globules due to the destruction of the fat globule membrane. In these conditions, the native milk enzyme lipase can attack the free fat, reducing the food quality [14].

In addition, during milk processing in heat exchangers, an excessive amount of air can act as nuclei for the formation of protein deposits that modify the heat transfer to milk and, consequently, the quality of this product can be adversely affected [9].

The de-aeration of milk by vacuum is one of the procedures that are applied to prevent the problems related to the presence of air. In the case of direct UHT milk, the elimination of steam after the heating step can give rise to a decrease of oxygen to values at which the oxidative reactions are avoided. In some indirect UHT and pasteurisation processes, to remove some volatile compounds and to improve the flavour of milk, the system is provided with a vacuum chamber placed before the heating section $[1,18]$.

Recently, Takeuchi et al. [17] have reported a patent where sterilisation is carried out after the dissolved oxygen in milk is substituted with nitrogen gas in order to improve the smell and taste of sterilised milk.

Determination of chemical changes that take place during processing of milk is mainly achieved to retrospectively assess the heat treatment or storage conditions to which milk has been submitted. Lactulose is formed by isomerisation of lactose via Lobry de Bruyn-Alberda van Ekenstein rearrangement [13] and furosine is originated after acid hydrolysis of the Amadori compounds, formed at the initial step of the Maillard reaction [5].

In spite of the number of works on the usefulness of lactulose and furosine as indicators of heat treatment, no data are available on the effect of air present in milk on their formation during heating processes. In this paper, we report a study on the effects of de-aeration of milk on lactulose and furosine formation during the heat treatment of milk at high temperatures.

\section{MATERIALS AND METHODS}

\subsection{Samples and heat treatments}

Batches of milk were purchased from a local dairy farm in the central region of Spain. With the aim of obtaining samples with the same initial content of air, the milk was previously de-aerated at $40{ }^{\circ} \mathrm{C}$ in a Rotavapor (Büchi RE 111, Switzerland) for $20 \mathrm{~min}$. After this procedure, portions $(\approx 30 \mathrm{~mL})$ of milk were subjected to three different types of treatment for $5 \mathrm{~min}$ : vacuum (Sample V), bubbling with nitrogen (Sample N) and bubbling with air (Sample A). Samples were heated in sealed Pyrex glass tubes $(25 \times 100 \mathrm{~mm})$ at 110 and $120^{\circ} \mathrm{C}$ several times in a thermostatically controlled temperature bath of silicone under continuous agitation. Heating was stopped by rapid cooling of the sealed Pyrex tubes in an ice-water bath. All assays were performed in duplicate. The $\mathrm{pH}$ of the samples was measured before and after the thermal treatments with a $\mathrm{pH}$-meter MicropH 2001 (Crison Instruments, Barcelona, Spain).

\subsection{Measurement of lactulose}

Lactulose levels were determined by means of gas chromatography of the 
trimethylsilyl derivatives of the free carbohydrate fraction using a Varian 3380 gas chromatograph (Varian Associates, Madrid, Spain) equipped with a $3 \mathrm{~m} \times 1.0 \mathrm{~mm}$ i.d. stainless steel column (Chrompack, Middelburg, The Netherlands) packed with $2 \%$ OV-17 on non-silanised 120/140 Volaspher A-2 (E. Merck AG, Darmstadt, Germany). One millilitre of milk was mixed with $1 \mathrm{~mL}$ of $1 \%$ phenyl- $\beta$-Dglucoside (internal standard) in 70\% methanol. The mixture was diluted to $10 \mathrm{~mL}$ with methanol, kept for $1 \mathrm{~h}$ at room temperature and filtered. One millilitre of the filtrate was evaporated under vacuum at $30{ }^{\circ} \mathrm{C}$ and converted to trimethylsilyl derivatives using $\mathrm{N}$-trimethylsilylimidazole [11].

In milk samples with a content of lactulose lower than $60 \mathrm{mg} \cdot \mathrm{L}^{-1}$ a modification of the sample preparation was performed according to the method of De Rafael et al. [3]. Milk samples $(2.5 \mathrm{~mL})$ were gently mixed with approximately $10 \mathrm{~mL}$ ethanol in a $25 \mathrm{~mL}$ volumetric flask, so that denatured protein particles would not get stuck above the volume mark; the flasks were filled to the volume mark by adding additional ethanol. After mixing again, the mixture was held for $48 \mathrm{~h}$ at room temperature to allow precipitation of lactose. Four millilitres of supernatant were mixed with $1 \mathrm{~mL} \quad 0.05 \%$ phenyl- $\beta-\mathrm{D}$ glucoside in $70 \%$ methanol, evaporated under vacuum at room temperature and converted to trimethylsilyl derivatives using $\mathrm{N}$-trimethylsilylimidazole.

\subsection{Measurement of furosine}

Two millilitres of milk were hydrolysed under inert conditions at $110{ }^{\circ} \mathrm{C}$ for $23 \mathrm{~h}$ in sealed tubes with $6 \mathrm{~mL}$ of $10.6 \mathrm{~mol} \cdot \mathrm{L}^{-1}$ $\mathrm{HCl}, 7.95 \mathrm{~mol} \cdot \mathrm{L}^{-1}$ being the final concentration. Furosine was determined by ion-pair reversed-phase HPLC according to the method reported by Resmini et al. [12]. The analyses were performed in a $\mathrm{C}_{8}$ column $(250 \times 4.6 \mathrm{~mm}$ inside diameter) (Alltech
Furosine-dedicated; Alltech Associates, Laarne, Belgium) and calibration curves were constructed using the standard of furosine (Neosystem Laboratories, Strasbourg, France).

\subsection{Determination of dissolved oxygen}

The content of oxygen was measured at $20^{\circ} \mathrm{C}$ using an Optosen ${ }^{\circledR}$ multichannel sensor system provided with a fibreoptic chemical sensor based on fluorescence measurements (Interlab, Electronics and Control Engineering, Madrid, Spain).

\subsection{Statistical analysis}

Analysis of the variance of the data was carried out using the SPSS program [15].

\section{RESULTS AND DISCUSSION}

Changes in the $\mathrm{pH}$ of the samples are shown in Figure 1 ( $a$ and b). As expected, the $\mathrm{pH}$ of the milks decreased during heating. This can be attributed to different factors: dissociation of phosphate radicals due to the precipitation of tricalcium phosphate [8] and decomposition of lactose into organic acids $[2,16]$. In general, for the same temperature-time conditions, hardly any differences were observed between the $\mathrm{pH}$ values of the milk samples.

The contents of dissolved oxygen (results not shown) in samples subjected for 5 min to vacuum (Sample V), bubbling with nitrogen (Sample N) or bubbling with air (Sample A) were $3.0( \pm 0.1) \mathrm{mg} \cdot \mathrm{L}^{-1}$, $2.5( \pm 0.2) \mathrm{mg} \cdot \mathrm{L}^{-1}$ and $6.3( \pm 0.2) \mathrm{mg} \cdot \mathrm{L}^{-1}$, respectively. $\mathrm{V}$ and $\mathrm{N}$ samples had a similar content of oxygen, whereas, in sample A, this level was much higher and close to that found in the initial milk $\left(7 \mathrm{mg} \cdot \mathrm{L}^{-1}\right)$ and in commercial raw milks reported by other authors [7]. Therefore, we assumed that aerated milk (sample A) has similar behaviour to mixed raw milk during heat treatment. 

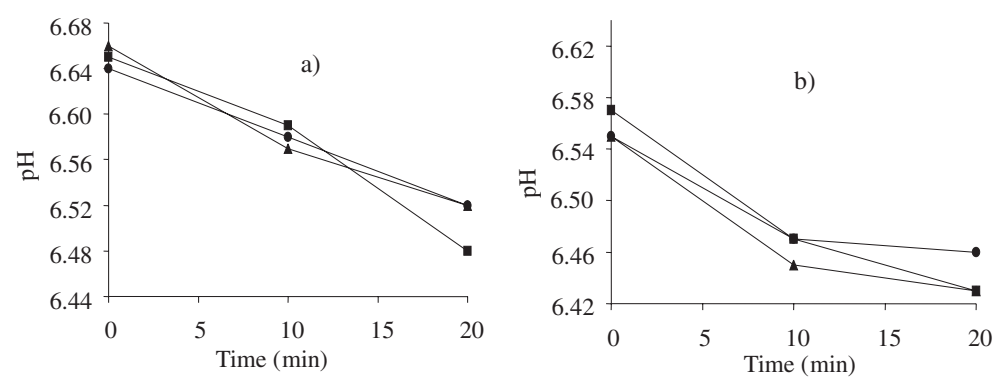

Figure 1. Evolution of $\mathrm{pH}$ during the heating of milk samples at $110{ }^{\circ} \mathrm{C}(\mathrm{a})$ and $120{ }^{\circ} \mathrm{C}(\mathrm{b})$ : nitrogen $(\boldsymbol{\square})$, vacuum $(\mathbf{\Delta})$ and air $(\bullet)$.

Table I shows the effect of the presence of gases on the formation of lactulose and furosine during heat treatment of milk at 110 and $120^{\circ} \mathrm{C}$. As expected, both lactulose and furosine increased in all samples with the intensity of heating. The amounts of lactulose and furosine in the heat-treated samples were lower in the airbubbled milk than in the nitrogen-bubbled or vacuum-treated milks. These differences were more pronounced in lactulose than in furosine. In the case of furosine slight differences were detected over a prolonged period of heating (20 min).
The analysis of variance including both parameters, lactulose and furosine, revealed significant differences $(P \leq 0.05)$ between samples bubbled with air and the de-aerated samples (with vacuum and nitrogen) for all the heat treatments applied, except for furosine in samples subjected to a prolonged period of heating $(20 \mathrm{~min})$.

During the early stages of the Maillard reaction as well as during lactose isomerisation, enediols are key intermediates. In the presence of oxygen, as in the case of milk samples bubbled with air, the double bond of these enediols may be cleaved to

Table I. Formation of lactulose and furosine $\left(\mathrm{mg} \cdot \mathrm{L}^{-1}\right)$ in samples treated with nitrogen $(\mathrm{N})$, vacuum (V) and air (A) and heated at 110 and $120^{\circ} \mathrm{C}$. Data are mean values \pm standard deviation.

\begin{tabular}{|c|c|c|c|c|c|c|c|}
\hline \multirow{2}{*}{$\begin{array}{l}\text { Chemical } \\
\text { parameter }\end{array}$} & \multirow[t]{2}{*}{ Samples } & \multicolumn{4}{|c|}{$110^{\circ} \mathrm{C}$} & \multicolumn{2}{|c|}{$120^{\circ} \mathrm{C}$} \\
\hline & & $5 \mathrm{~min}$ & $7 \mathrm{~min}$ & $10 \mathrm{~min}$ & $20 \mathrm{~min}$ & $10 \mathrm{~min}$ & $20 \mathrm{~min}$ \\
\hline \multirow{3}{*}{ Lactulose } & $\mathrm{N}$ & $\mathrm{nd}^{*}$ & nd & $71.0 \pm 5.7$ & $701.0 \pm 24.0$ & $177.0 \pm 7.1$ & $1199.0 \pm 90.5$ \\
\hline & $\mathrm{V}$ & $30.5 \pm 0.8$ & $58.1 \pm 3.8$ & $86.0 \pm 2.8$ & $720.0 \pm 48.1$ & $171.0 \pm 7.1$ & $1123.0 \pm 26.9$ \\
\hline & A & $27.1 \pm 1.7$ & $37.7 \pm 1.2$ & $59.6 \pm 3.5$ & $562.0 \pm 43.8$ & $78.5 \pm 6.4$ & $733.5 \pm 44.5$ \\
\hline \multirow{3}{*}{ Furosine } & $\mathrm{N}$ & nd & nd & $26.6 \pm 1.9$ & $113.9 \pm 1.2$ & $36.2 \pm 1.9$ & $143.0 \pm 9.0$ \\
\hline & V & $6.2 \pm 0.1$ & $9.3 \pm 0.4$ & $23.5 \pm 2.2$ & $117.0 \pm 3.6$ & $40.2 \pm 0.0$ & $135.8 \pm 7.3$ \\
\hline & A & $4.9 \pm 0.1$ & $7.0 \pm 0.0$ & $13.6 \pm 0.4$ & $106.9 \pm 5.3$ & $25.5 \pm 2.1$ & $130.8 \pm 7.3$ \\
\hline
\end{tabular}

* nd: not determined. 
produce two carboxylic acids [10]. The degradation of the enediol caused a decrease in the formation of lactulose and the Amadori compound $\varepsilon$-desoxylactulosyl-lysine, a precursor of furosine. On the contrary, treatment with vacuum or bubbling with nitrogen caused the removal of dissolved oxygen, avoiding the oxidative cleavage of the enediols.

The noticeably greater effect of the presence of oxygen on the formation of lactulose seems to indicate that the enediol precursor of lactulose is more oxygen-sensitive than that of the Amadori compound. At prolonged periods of heating, when a considerable proportion of dissolved oxygen has been consumed, the effect on the formation of the Amadori compound may be negligible, resulting in small differences in the furosine content between samples.

Although no data are reported on the influence of oxygen on the Maillard reaction in milk, several authors have studied the effects of oxygen on this reaction in model systems. Thus, Hayase et al. [6] observed less browning under aerobic conditions. Yeboah et al. [20,21], studying the glycation of proteins via the Maillard reaction, demonstrated that the presence of oxygen in the reaction system induces oxidative side reactions, which can slow the initial rate of formation of Amadori compounds.

These results indicate that dissolved oxygen has a significant effect on the formation of lactulose and furosine in heated milks. Since these compounds have proved effective indicators of the quality of processed milks, before using them to assess the quality of commercial milks, more extensive studies on the effects of dissolved gases on the formation of lactulose and furosine are needed.

\section{ACKNOWLEDGEMENTS}

This work was supported by the project ALI98-0969-C02-01. The authors thank G. Orellana and M. Bedoya for the determinations of dissolved oxygen.

\section{REFERENCES}

[1] Amiot J., Leche de consumo, in: Foundation of Dairy Technology from Québec, Canada (Eds.) Ciencia y Tecnología de la leche. Acribia S. A. Zaragoza, Spain, 1991, pp. 195-218.

[2] Berg H.E., Reactions of lactose during heat treatment of milk: a quantitative study. Thesis ISBN 90-5485-102-3. Agricultural University, Wageningen, The Netherlands, 1993.

[3] De Rafael D., Calvo M.M., Olano A., Determination of low levels of lactulose in milk, Milchwissenschaft 51 (1996) 552-553.

[4] Eitenmiller R.R., Landen W.O.Jr., Ascorbic acid Vitamin C, in: Eitenmiller R.R., Landen W.O. (Eds.), Vitamin analysis for the health and food sciences. CRC Press, Boca Raton, USA, 1999, pp. 223-270.

[5] Erbersdobler H.F., Twenty years of furosinebetter knowledge about the biological significance of Maillard reaction in food and nutrition, in: Fujimaki M., Namiki M., Kato H. (Eds.), Amino-carbonyl reactions in food and biological systems, Elsevier Scientific Publishing Co. Amsterdam, The Netherlands, 1986, pp. 481-502.

[6] Hayase F., Shibuya T., Sato J., Yamamoto M., Effects of oxygen and transition metals on the advanced Maillard reaction of proteins with glucose, Biosci. Biotechnol. Biochem. 60 (1996) 1820-1825.

[7] Jenness R., Composition of milk, in: Wong N.P. (Ed.), Fundamentals of dairy chemistry, Van Nostrand Reinhold Company, New York, USA, 1988, pp. 1-38.

[8] Jenness R., Koops J., Preparation and properties of a salt solution which simulates milk ultrafiltrate, Neth. Milk Dairy J. 16 (1962) 153-164

[9] Jeurnink T.J.M., Walstra P., de Kruif C.G., Mechanisms of fouling in dairy processing, Neth. Milk Dairy J. 50 (1996) 407-426.

[10] O'Brien J., Heat-induced changes in lactose: isomerization, degradation, Maillard browning, in: Heat-induced changes in milk, special issue 9501, Int. Dairy Fed., Brussels, Belgium, 1995, pp. 134-170.

[11] Olano A., Calvo M.M., Reglero G., Analysis of free carbohydrates in milk using micropacked columns, Chromatographia 21 (1986) 538-540.

[12] Resmini P., Pellegrino L., Battelli G., Accurate quantification of furosine in milk and dairy products by a direct HPLC method, Ital. J. Food Sci. 3 (1990) 173-183.

[13] Richards E.L., Chandrasekhara M.R., Chemical changes in dried skim milk during storage, J. Dairy Res. 27 (1960) 59-66. 
[14] Spreer E., Composition and characteristics of milk, in: Spreer E. (Ed.), Milk and dairy product technology, Marcel Dekker Inc., New York, USA, 1998, pp. 11-39.

[15] SPSS for Windows v. 9.0.1 (1989-1999). SPSS Inc., Chicago, Illinois, USA.

[16] Sweetsur A.W.M., White J.C.D., Studies on the stability of milk protein. III. Effect of heat induced acidity in milk, J. Dairy Res. 42 (1975) 73-88.

[17] Takeuchi Y., Kudo S., Inagaki H., Kamiya T., Toyoda I., A sterilising method by substituting the dissolved oxygen in milk or the like with nitrogen gas, a product thereof and an apparatus for nitrogen gas substitution, Patent number EP1082907 (2001).
[18] Veisseyre R., Tecnología de las leches de consumo, in: Veisseyre R. (Ed.), Lactología técnica. ACRIBIA, Zaragoza, Spain, 1980, pp. 182-238.

[19] Vidal-Valverde C., Ruiz R., Medrano A., Stability of retinol in milk during frozen and other storage conditions, Z. Lebensm. Unters. Forsch. 195 (1992) 562-565.

[20] Yeboah F.K., Alli I., Yaylayan V.A., Reactivities of D-glucose and D-fructose during glycation of bovine serum albumin, J. Agric. Food Chem. 47 (1999) 3164-3172.

[21] Yeboah F.K., Alli I., Yaylayan V.A., Konishi Y., Stefanowicz P., Monitoring glycation of lysozyme by electrospray ionization mass spectrometry, J. Agric. Food Chem. 48 (2000) 2766-2774.

To access this jounal online: www.edpsciences.org 